\title{
Front Matter: Volume 6674
}

, "Front Matter: Volume 6674," Proc. SPIE 6674, Thin-Film Coatings for Optical Applications IV, 667401 (25 September 2007); doi: 10.1117/12.773514

SPIE Event: Optical Engineering + Applications, 2007, San Diego, California, United SPIE. States 


\section{PROCEEDINGS OF SPIE}

\section{Thin-Film Coatings for Optical Applications IV}

Michael J. Ellison

Editor

29-30 August 2007

San Diego, California, USA

Sponsored and Published by

SPIE 
The papers included in this volume were part of the technical conference cited on the cover and title page. Papers were selected and subject to review by the editors and conference program committee. Some conference presentations may not be available for publication. The papers published in these proceedings reflect the work and thoughts of the authors and are published herein as submitted. The publisher is not responsible for the validity of the information or for any outcomes resulting from reliance thereon.

Please use the following format to cite material from this book:

Author(s), "Title of Paper," in Thin-Film Coatings for Optical Applications IV, edited by

Michael J. Ellison, Proceedings of SPIE Vol. 6674 (SPIE, Bellingham, WA, 2007) Article CID Number.

ISSN 0277-786X

ISBN 9780819468222

Published by

SPIE

P.O. Box 10, Bellingham, Washington 98227-0010 USA

Telephone +1 3606763290 (Pacific Time) · Fax +1 3606471445

SPIE.org

Copyright (C 2007, Society of Photo-Optical Instrumentation Engineers

Copying of material in this book for internal or personal use, or for the internal or personal use of specific clients, beyond the fair use provisions granted by the U.S. Copyright Law is authorized by SPIE subject to payment of copying fees. The Transactional Reporting Service base fee for this volume is $\$ 18.00$ per article (or portion thereof), which should be paid directly to the Copyright Clearance Center (CCC), 222 Rosewood Drive, Danvers, MA 01923. Payment may also be made electronically through CCC Online at copyright.com. Other copying for republication, resale, advertising or promotion, or any form of systematic or multiple reproduction of any material in this book is prohibited except with permission in writing from the publisher. The CCC fee code is $0277-786 \mathrm{X} / 07 / \$ 18.00$.

Printed in the United States of America.

Publication of record for individual papers is online in the SPIE Digital Library.

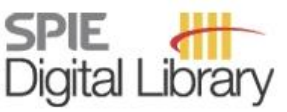

SPIEDigitalLibrary.org

Paper Numbering: Proceedings of SPIE follow an e-First publication model, with papers published first online and then in print and on CD-ROM. Papers are published as they are submitted and meet publication criteria. A unique, consistent, permanent citation identifier (CID) number is assigned to each article at the time of the first publication. Utilization of CIDs allows articles to be fully citable as soon they are published online, and connects the same identifier to all online, print, and electronic versions of the publication. SPIE uses a six-digit CID article numbering system in which:

- The first four digits correspond to the SPIE volume number.

- The last two digits indicate publication order within the volume using a Base 36 numbering system employing both numerals and letters. These two-number sets start with 00, 01, 02, 03, 04, 05, $06,07,08,09,0 A, 0 B \ldots 0 Z$, followed by 10-1Z, 20-2Z, etc.

The CID number appears on each page of the manuscript. The complete citation is used on the first page, and an abbreviated version on subsequent pages. Numbers in the index correspond to the last two digits of the six-digit CID number. 


\section{Contents}

$\checkmark$ Introduction

\section{SESSION 1 INNOVATIVE FILM STRUCTURES AND MEASUREMENTS}

667402 Simultaneous measurements of thin-film thickness and refractive index by dispersive whitelight interferometry [6674-01]

Y.-S. Ghim, J. You, S.-W. Kim, Korea Advanced Institute of Science and Technology (South Korea)

667403 Conductive distributed Bragg reflector fabricated by oblique angle deposition from a single material [6674-02]

M. F. Schubert, J. K. Kim, S. Chhajed, E. F. Schubert, Rensselaer Polytechnic Institute (USA)

667404 Aperiodic metal-dielectric optical filters [6674-03]

D. Owens, C. Fuentes-Hernandez, B. Kippelen, Georgia Institute of Technology (USA)

667405 Analyses of structural films using effective refractive index model [6674-04]

T.-H. Chang, Y.-W. Yeh, S.-H. Chen, C.-C. Lee, National Central Univ. (Taiwan)

\section{SESSION 2 NOVEL DEPOSITION TECHNIQUES}

667406 Robust antireflection coatings By UV cross-linking of silica nanoparticles and diazo-resin polycation [6674-06]

J. I. Ridley, J. R. Heflin, A. L. Ritter, Virginia Polytechnic Institute and State Univ. (USA)

667407 Vapor-phase-deposited organosilane coatings as hardening agents for high-peak-power laser optics [6674-07]

K. L. Marshall, Z. Culakova, B. Ashe, C. Giacofei, A. L. Rigatti, T. J. Kessler, A. W. Schmid,

J. B. Oliver, A. Kozlov, Univ. of Rochester (USA)

667408 Fabrication of indium tin oxide (ITO) thin films by spin-coating deposition method [6674-08]

P. Psuja, W. Strek, Institute of Low Temperature and Structure Research (Poland)

\section{SESSION 3 THIN-FILMS FOR SOLAR APPLICATIONS}

6674 OA Graded silicon based PECVD thin film for photovoltaic applications [6674-11]

M. Gharghi, S. Sivoththaman, Univ. of Waterloo (Canada)

$6674 \mathrm{OB}$ Fabrication of hydrogenated microcrystalline silicon thin films using RF magnetron sputtering [6674-12]

H.-W. Wang, W.-N. SU, C.-W. Han, S.-H. Chen, C.-C. Lee, National Central Univ. (Taiwan) 
POSTER SESSION

6674 OC ZnO based diluted magnetic semiconductor thin films by RF magnetron sputtering for spin photonic devices [6674-14]

J. Elanchezhiyan, K. P. Bhuvana, N. Gopalakrishnan, T. Balasubramanian, National Institute of Technology, Tiruchirappalli (India)

Author Index 


\section{Introduction}

This year's SPIE Conference on Advances in Thin-film Coatings for Optical Applications encompassed a wide range of deposition techniques and an equally wide range of uses for these coatings. The deposition techniques ranged from spin-coating to RF magnetron sputtering to oblique angle physical vapor deposition. The uses ranged from broadband anti-reflection to broadband conductive reflectors to power generation from solar cells.

This was the first year we had high-quality presentations describing the use of thinfilms in solar cell applications. It is hoped that this topic will grow in future years along with the use of solar cells themselves. The use of solar cells will inevitably become more widespread as we reduce our dependence on fossil fuels.

I do anticipate that these proceedings will be widely referenced and that readers will be able to discover both important technical details, which will aid their own process development, and new insights which might lead to completely novel applications of thin-film coatings.

It is often said that interesting things occur at interfaces. This is clearly the case where conflicting ideas interface and can be seen in the natural world with the profusion of life found at the interface of land and sea. Likewise, myriad and fascinating phenomena occur at the interface of substrate and optical medium. For this reason, thin-film coatings will remain fertile ground for innovation for the foreseeable future.

I would like to thank the organizers at SPIE who do a wonderful job, and also thank especially, all the contributors. Without your excellent work this conference could not have been a success.

Michael J. Ellison 
Downloaded From: https://www.spiedigitallibrary.org/conference-proceedings-of-spie on 26 Apr 2023

Terms of Use: https://www.spiedigitallibrary.org/terms-of-use 